\title{
Damage from lava flows: insights from the 2014-2015 eruption of Fogo, Cape Verde
}

\author{
S. F. Jenkins ${ }^{1,2^{*}}$, S. J. Day ${ }^{3}$, B. V. E. Faria ${ }^{4}$ and J. F. B. D. Fonseca ${ }^{5}$
}

\begin{abstract}
Fast-moving lava flows during the 2014-2015 eruption of Fogo volcano in Cape Verde engulfed 75\% $(n=260)$ of buildings within three villages in the Chã das Caldeiras area, as well as $25 \%$ of cultivable agricultural land, water storage facilities and the only road into the area. The eruption had a catastrophic impact for the closeknit communities of Chã, destroying much of their property, land and livelihoods. Volcanic risk assessment typically assumes that any object - be it a building, infrastructure or agriculture - in the path of a lava flow will be completely destroyed. Vulnerability or fragility functions for areas impacted by lava flows are thus binary: no damage in the absence of lava and complete destruction in the presence of lava. A pre-eruption field assessment of the vulnerability of buildings, infrastructure and agriculture on Fogo to the range of volcanic hazards was carried out in 2010. Many of the areas assessed were subsequently impacted by the 2014-2015 eruption and, shortly after the eruption ended, we carried out a post-eruption field assessment of the damage caused by the lava flows. In this paper, we present our findings from the damage assessment in the context of building and infrastructural vulnerability to lava flows. We found that a binary vulnerability function for lava flow impact was appropriate for most combinations of lava flow hazard and asset characteristics but that building and infrastructure type, and the flow thickness, affected the level of impact. Drawing on these observations, we have considered potential strategies for reducing physical vulnerability to lava flow impact, with a focus on buildings housing critical infrastructure. Damage assessments for lava flows are rare, and the findings and analysis presented here are important for understanding future hazard and reconstruction on Fogo and elsewhere.

Keywords: Fogo, Cape Verde, Lava flows, Building, infrastructural and agricultural damage, eruption impact assessment, hazard and risk assessment, mitigation
\end{abstract}

\section{Introduction}

Lava flows are Earth's most common volcanic feature and one of the most easily-recognised products of a volcanic eruption (Kilburn 2015). They can be categorised into three main types, according to their surface features: pāhoehoe, ' $a$ 'ā and blocky and all three may occur within the same eruption. Blocky flows are associated with more viscous lava and can be tens of metres thick, while pāhoehoe and 'a'ā can be produced by chemically identical mafic lavas moving at different velocities (faster in the case of ' $a$ 'a $\bar{a}$, at least initially). These types of flow are more commonly 2-10 m thick, although pāhoehoe flows can be thinner, particularly on initial emplacement

\footnotetext{
* Correspondence: Susanna.Jenkins@ntu.edu.sg

${ }^{1}$ School of Earth Sciences, University of Bristol, Bristol, UK

${ }^{2}$ Earth Observatory of Singapore, Nanyang Technological University,

Singapore, Singapore

Full list of author information is available at the end of the article
}

(Kilburn 2015). Their subsequent thickening, or inflation, due to continued movement of magma into the interior of the flow is common, but varies from case to case according to the history of magma input to the flow (Calvari and Pinkerton 1998; Walker 2009). During relatively high effusion rate eruptions, sheet flows can also form where fluid lava ponds in low-lying areas or where individual lobes of lava coalesce, or at lava flow breakouts where local effusion rates are transiently elevated (Kilburn 2015). The area impacted by a lava flow depends upon a number of factors including the vent location and local topography, and the effusion rate and duration.

Descriptions of past lava flow impacts are limited and relatively few studies (e.g. Behncke et al. 2005; Felpeto et al. 2001; Rhodes et al. 2013) have directly assessed the future threat of lava flows to buildings, infrastructure or agriculture. For an overview of the historical impacts of 
lava flows see Blong (1984) and the updated review of Harris (2015). Over the past decades there have been a number of lava flow impacts in populated areas (Table 1). The largest lava flow impact of recent times took place during the 2002 eruption of Nyiragongo, Democratic Republic of Congo, in which lava flows destroyed approximately $15 \%$ of the city of Goma and the homes of more than 120,000 people (Baxter et al. 2002). Nyiragongo had previously erupted in 1977 destroying the homes of around 800 people (Blong 1984). The number of buildings damaged or destroyed by lava flows in the Chã das Caldeiras area during the 2014-2015 eruption of Fogo volcano in Cape Verde was much smaller $(n=260)$ than at Goma. However, a greater proportion of buildings in Chã das Caldeiras were affected, and the community's isolation relative to the rest of the island's inhabitants and their reliance upon now-buried agricultural land means that the short- and long-term consequences of the lava flows for the community are likely to be significant.

In volcanic risk assessment, anything impacted by a lava flow is expected to be completely destroyed so that fragility functions, which relate the hazard intensity to a probability of damage or disruption, are considered binary: lava results in complete destruction; no lava results in no damage (Jenkins et al. 2014). This is in contrast to most volcanic hazards, which show a gradational fragility (or vulnerability) function or curve. As a result, little attention has been paid to possible relationships between morphological, kinematic and mechanical features of lava flows and the intensities of the resulting hazards to different assets, such as land, buildings and infrastructure. In 2010, an assessment of the physical vulnerability of Fogo's building stock and agricultural infrastructure to volcanic hazards was carried out as part of the European FP7 MIA-VITA (MItigate and Assess risk from Volcanic Impact on Terrain and human Activities) project (Jenkins et al. 2014). For lava flows, the likely loss was assumed to be complete should an area be inundated by lava. However, some of the assessed areas have since been impacted by lava during the 2014-2015 eruption, allowing us to test this assumption. A good knowledge and understanding of the pre-eruption infrastructure, context and setting helped us in carrying out a field study to assess the impact of the 2014-2015 eruption on buildings, infrastructure and agriculture. This paper describes and discusses our findings, with the text split into four main components:

Section 2: We introduce Fogo volcano and its pre-2014 eruption history, describe the main characteristics of buildings, infrastructure and agriculture as determined through the pre-eruption vulnerability assessment, and provide a detailed overview and timeline for the 2014-2015 eruption;

Section 3: We outline the methods employed in our remote and field impact assessments, describing how satellite images, media reports and field data were used to quantify the impacts of the 2014-2015 Fogo lava flows;

Section 4: We present our findings from the posteruption impact assessment undertaken in early 2015. Building damage is described according to the different levels of damage sustained by buildings in Chã, while damage to infrastructure and agriculture is described for each sector, e.g. roads, telecommunications, in turn;

Table 1 Notable building damage (>20 houses destroyed) by lava flows in the period 1965-2015. Data sourced from Blong (1984) and Harris (2015) and supplemented with references noted in the table

\begin{tabular}{|c|c|c|c|}
\hline Volcano & Date & Building damage description & Source \\
\hline Vestmannaeyjar, Iceland & 1973-1974 & $\begin{array}{l}\text { Approximately } 300 \text { houses in Heimaey town } \\
\text { destroyed by lava or fire. }\end{array}$ & Williams and Moore (1983) \\
\hline Karangetang (Api Siau), Indonesia & 1976 & $\begin{array}{l}24 \text { houses destroyed (and a further } 44 \text { in the } \\
\text { path of the flow dismantled) }\end{array}$ & $\begin{array}{l}\text { Global Volcanism Program } \\
\text { (1976) }\end{array}$ \\
\hline $\begin{array}{l}\text { Nyiragongo, Democratic Republic } \\
\text { of Congo }\end{array}$ & 1977 & $\begin{array}{l}\text { Approximately } 400 \text { houses in two villages } \\
\text { destroyed, and } 12 \mathrm{~km}^{2} \text { of agricultural land } \\
\text { buried. }\end{array}$ & $\begin{array}{l}\text { Global Volcanism Program } \\
\text { (1977a) }\end{array}$ \\
\hline Piton de la Fournaisse, Réunion & 1977 & $\begin{array}{l}33 \text { houses and a church in Piton Sainte Rose } \\
\text { were destroyed. The road was also buried. }\end{array}$ & $\begin{array}{l}\text { Global Volcanism Program } \\
\text { (1977b) }\end{array}$ \\
\hline Kïlauea, USA & 1986, and 1990-1991 & $\begin{array}{l}181 \text { buildings - the majority of Kalapana } \\
\text { town -destroyed, mostly during the } 1990-1991 \\
\text { lava flows. More than } 10 \mathrm{~km} \text { of public highway } \\
\text { was buried. }\end{array}$ & $\begin{array}{l}\text { Global Volcanism Program } \\
\text { (1992) }\end{array}$ \\
\hline $\begin{array}{l}\text { Nyiragongo, Democratic Republic } \\
\text { of Congo }\end{array}$ & 2002 & 4500 buildings destroyed. & Baxter et al. (2002) \\
\hline Fogo, Cape Verde & 2014-2015 & $\begin{array}{l}170 \text { buildings destroyed, } 90 \text { damaged. The } \\
\text { only road was buried, along with } \sim 2 \mathrm{~km}^{2} \\
\text { of agricultural land ( } 25 \% \text { of all cultivable land) }\end{array}$ & This study and PDNA, 2016 \\
\hline
\end{tabular}


Section 5: We discuss our findings and their implications, in particular the assumption of a binary fragility function in lava flow risk assessment, and the lava flow parameters and properties that control the fragility functions. In this section we also propose some building design strategies that could reduce the physical vulnerability of typical buildings and buildings housing critical infrastructure.

\section{Background}

\section{Fogo volcano}

The approximately $25 \mathrm{~km}$ wide island of Fogo is formed almost entirely from a single large and steep-sided shield volcano (Fig. 1). It is the most active volcano in the Cape Verde hotspot archipelago and lies around $800 \mathrm{~km}$ west of Senegal in Africa. The steep summit cone of Pico do Fogo rises to $\sim 2830 \mathrm{~m}$ above sea level and sits within the more than 80,000 years old Monte Amarelo lateral collapse structure that is $9 \mathrm{~km}$ wide, open towards the east and associated with debris avalanche deposits on the ocean floor (Day et al. 1999; Fonseca et al. 2003; Masson et al. 2008). The upper part of the collapse scar, the Bordeira cliff, is still up to $1 \mathrm{~km}$ high in places and effectively protects most of the island from lavas erupted within the scar (Fig. 1). The east side of the island, which is within the collapse scar, and areas in the northeast and southeast, which are adjacent to sections of the collapse scar cliff that have been completely buried by post-collapse lavas, are not protected in this way and are susceptible to lava flows from Pico and within the collapse scar. Between Pico and the Bordeira cliffs, there is a flat area called Chã das Caldeiras ("plain of craters") formed by ponding of lavas between Pico and the cliffs (Fig. 1). Chã is one of the most productive agricultural areas in semi-arid Cape Verde, owing to relatively reliable orographic rainfall in the summer and autumn months. It has been inhabited since the mid- $19^{\text {th }}$ century, with the main villages of Portela and Bangaeira assuming their present organisation in the early $20^{\text {th }}$ Century (Fernandes and Faria 2015).

Major natural hazards on the island as a whole are from floods and rockfalls, although in Chã and along the eastern flank, effusive eruptions and lava flows are also important. However, by far the most important natural hazard in Fogo, as in Cape Verde as a whole, is drought. Although the effects of droughts since 1950 have been effectively mitigated by food imports, in previous decades large scale mortality occurred in Cape Verde as a

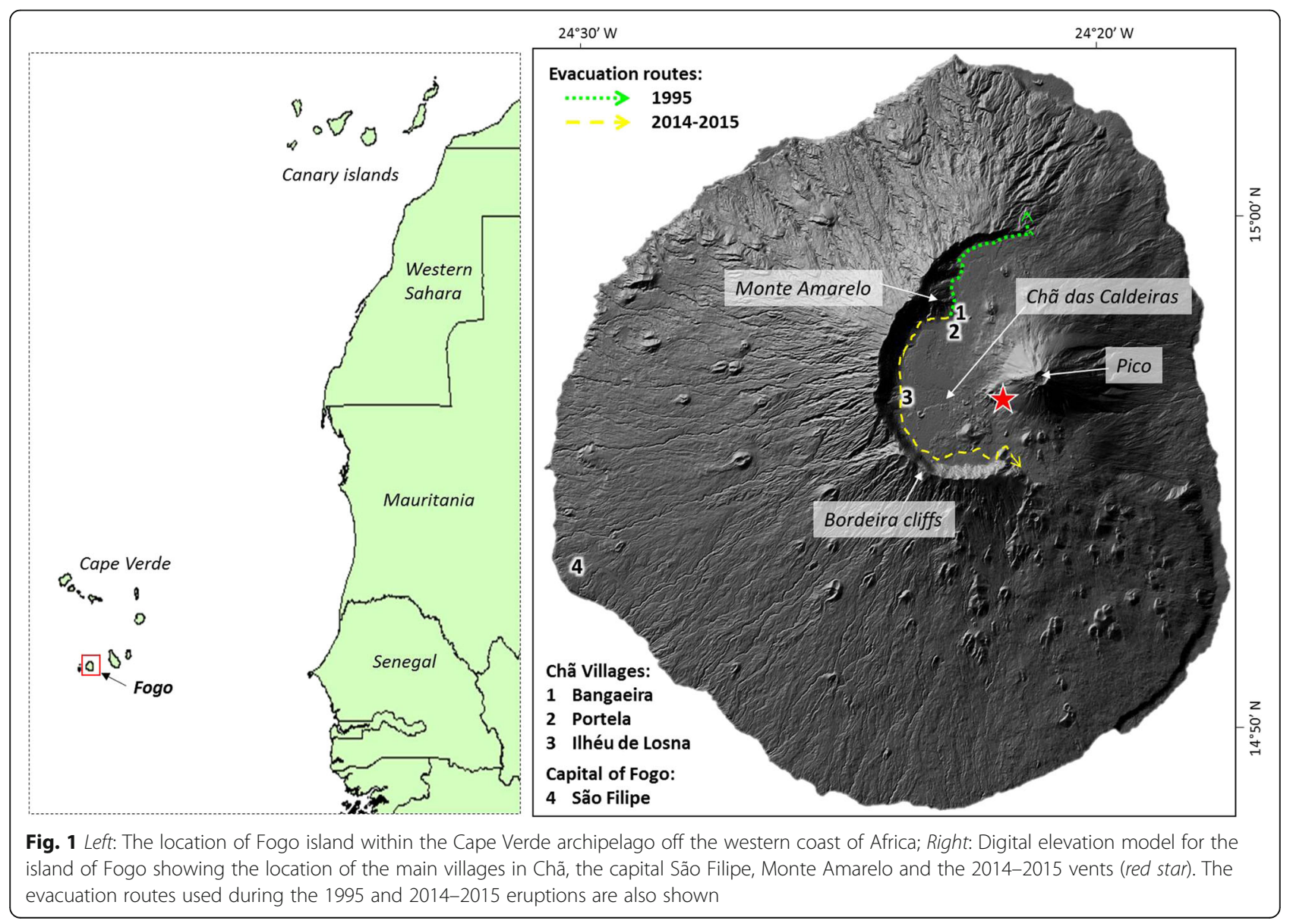


result of multi-year droughts; most notably in $1810 \mathrm{AD}$, $1830 \mathrm{AD}$, and from 1941 through to the late 1940s (WorldAtlas 2011). In 2014, Cape Verde received 65\% less rain than 2013 (FAO 2015) and the region was experiencing severe drought at the time of the 2014-2015 eruption. This history of droughts goes some way towards explaining the strong attachment of the inhabitants of Chã das Caldeiras to their land, and their reluctance to be resettled on the more arid south side of Fogo in the aftermath of recent eruptions as discussed below.

\section{Previous eruptions}

Historical accounts from the early stages of Portuguese settlement in the $15^{\text {th }}$ Century through to about $1725 \mathrm{AD}$ indicate that Fogo volcano experienced frequent eruptions from the summit and from flank fissures on all sides of the Pico (Day et al. 2000; Fonseca et al. 2003; Ribeiro 1960). In 1680 AD, a major summit eruption of Pico do Fogo produced large ash falls over the whole island rendering agricultural lands temporarily unusable and triggering mass emigration from the island, to Brava in particular (Ribeiro 1960). Most eruptions from $1725 \mathrm{AD}$ up to and including that in $1857 \mathrm{AD}$ were from fissure vents on the northern and southern flanks of the Pico and Fogo (Faria and Fonseca 2014). In the 150 years or so since first settlement of Chã das Caldeiras there have been three effusive eruptions that occurred from subsidiary flank vents near the base of Pico: in 1951, 1995 and 2014-2015 (Fig. 2). All three of these eruptions were from fissure vent arrays located farther west than any other post- 1725 AD vents and, in the case of the 1995 and 2014-2015 eruptions, from mainly northeast-southwest trending fissures within Chã (Faria and Fonseca 2014).

The 1951 eruption, from vents both north-west and south of the Pico do Fogo, had relatively little net impact upon Chã das Caldeiras. Some fields to the east of Portela and Bangaeira were covered by lavas, which also destroyed a few houses in Bangaeira (Pers. Comm. to Simon Day from Sr. Antonio Teixeira, 2002). More damage due to lava flows occurred outside rather than inside Chã das Caldeiras, as lava flows from the southern vents covered fields and houses in the south east of the island (Ribeiro 1960; Pers. Comm. to Simon Day from Sr. Antonio Teixeira, 2002). On the other hand, lapilli falls around the north-western vents covered some older lava flows, providing areas that proved suitable for small-scale commercial agriculture (producing apples, quince and grapes) in later years.

At the time of the 1995 eruption, Chã was home to approximately 1300 people (Bulletin of the Global Volcanism Network 1995) in three villages: the larger and densely packed villages of Portela and Bangaeira and the smaller and less densely populated Ilhéu de Losna (Figs. 1 and 2) as well as scattered houses around Chã. The 1995 lava flows cut the main road into Chã early in the eruption, leading to a difficult evacuation of the villages via footpaths to the north coast of the island (Fig. 1). The lavas subsequently destroyed buildings and a water reservoir and, most importantly, over $3 \mathrm{~km}^{2}$ of fertile agricultural land. The agricultural land covered included most of an area west of Portela village that formed the best land in Chã das Caldeiras for growing a variety of food crops. The sale of most of these food crops (such as peas and beans) formed an important source of cash income to families not involved in tourism or in fruit and vine cultivation. After the 1995 eruption, communities and associated services such as health and education were permanently relocated outside of Chã to planned villages on the arid south side of Fogo with the aim of preventing future impacts. These planned villages lacked agricultural land, although they did allow easier access to public and commercial services in the main town of Fogo, São Filipe. Within 2 years Chã was being repopulated, mostly within Portela and Bangaeira villages, beginning with adults returning to work the fields. Over the following two decades, a burgeoning wine, agricultural and tourism industry developed.

By 2010, a census recorded 697 Chã das Caldeiras inhabitants, but estimates of resident numbers prior to the 2014-2015 eruption were as high as nearly 1500 (Global Volcanism Program 2014). The exposure and vulnerability to future lava flows was therefore, in broad terms, as high as it had been before the 1995 eruption. Furthermore, another 11,000 people in a number of villages on the steep eastern flanks of Fogo were exposed to over-spilling flows such as those that reached the east coast of the island in all eruptions between $1785 \mathrm{AD}$ and 1857 AD. Indeed, because of the potential for lava flows to descend the steep eastern slope of Fogo at speed, coupled with the dependence of these villages upon a single road for normal communications and emergency evacuation, managing lava flow risk in the east flank communities presented as much of a problem as it did for the communities in Chã das Caldeiras.

\section{Buildings, infrastructure and agriculture}

The pre-eruption vulnerability assessment in Chã das Caldeiras (Jenkins et al. 2014) found building types to be dominated by unreinforced masonry buildings, with approximately $40 \%$ of all buildings constructed from large locally-sourced lava blocks $40-60 \mathrm{~cm}$ thick. These include distinctive cylindrical one-storey rubble-stone traditional buildings, which are often used for shelter while tending agricultural lands or for storage or annex homes. Cooled and solidified lava blocks make very 

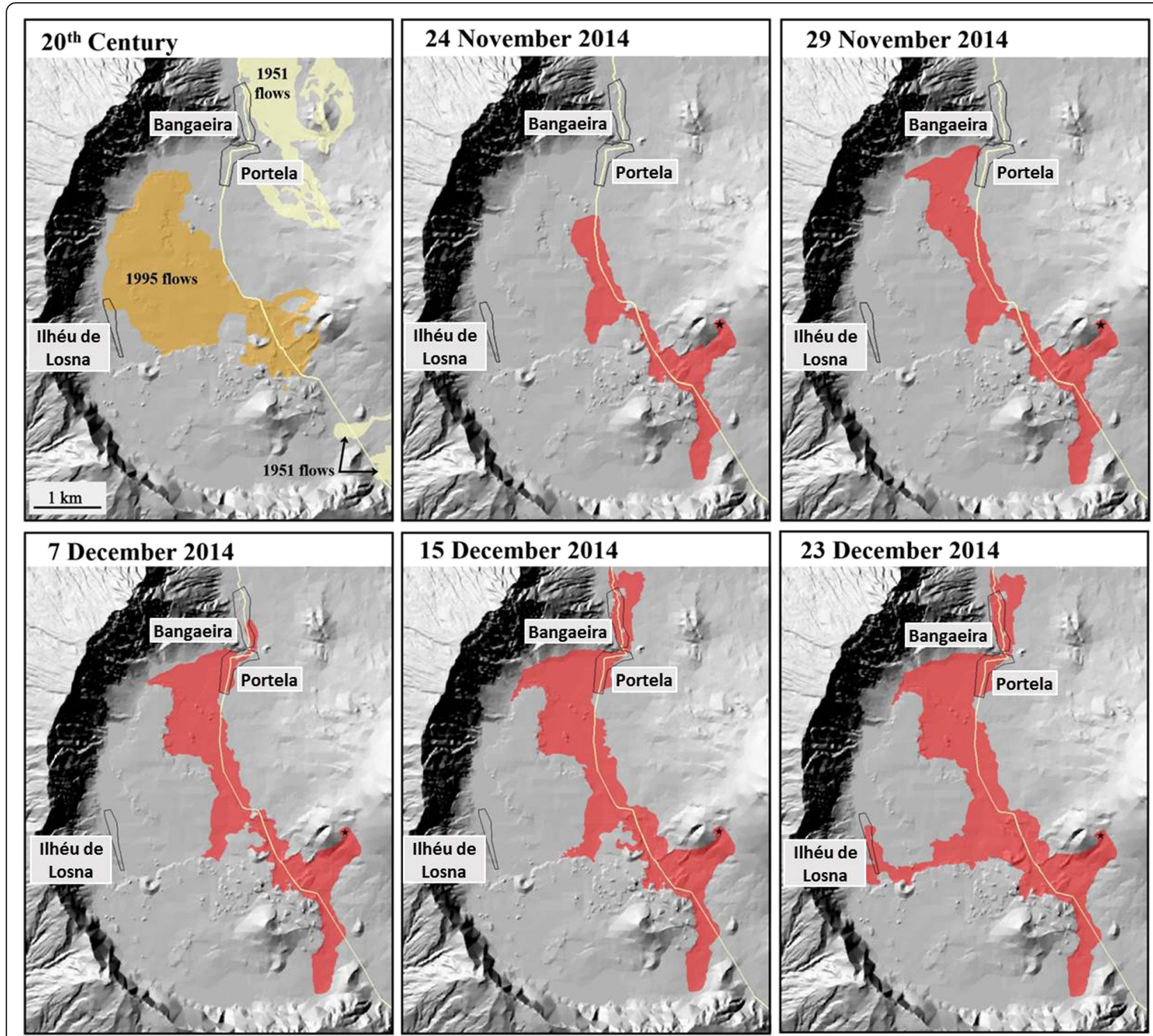

Fig. 2 Eruption evolution shown by lava flow maps sourced from satellite images on the dates shown, with outlines created from Orthophoto images sourced in the MIA-VITA project for the $20^{\text {th }}$ century outlines, and provided by the Copernicus Emergency Management Service (http://emergency.copernicus.eu EMSR111) for the 2014-2015 outlines. We have revised 2014-2015 lava flow outlines using field observations where possible. The three main villages of Chã (Bangaeira, Portela and Ilhéu de Losna) and the only road into the area are shown on each map

strong construction material for roads and buildings, and are valuable construction assets across Fogo. The remaining buildings were constructed using squared masonry or breeze blocks, around half with and half without a reinforced concrete frame. The construction quality of the frames and mortar, where present, was variably poor with the cement used as mortar or within the frame often showing large air gaps that would significantly weaken any steel reinforcement bars and the building's resistance to lateral pressures. Almost all of the buildings had flat reinforced concrete slab roofs that were used to collect rainwater, the predominant source for water in Chã, which was then stored in concrete, plastic or metal tanks. A small number of buildings had tiled or metal sheet roofs (Jenkins et al. 2014). The pre-eruption vulnerability assessments forecast complete loss in areas affected by lava flow; however, the thick walls of rubble stone construction were recognised to be particularly resistant to lateral loading from a flow (Jenkins et al. 2014).

Very little infrastructure existed in Chã prior to 2014. The only road into the area constructed of cobble-sized lava blocks sourced from previous lava flows and raised up to $2 \mathrm{~m}$ above the surrounding flat topography in places, cutting levees and other elevated parts of old lava flows in other places. Communication cables carried to 
the villages on timber utility poles followed the route of the road. Generators provided power for residents at night and cooking was fuelled by bottled gas transported by road from São Filipe. In addition to rainwater, small springs at the foot of the Bordeira cliffs between Portela and Boca de Fonte, which are tens of metres above the level of Chã, and a $370 \mathrm{~m}$ deep borehole a few hundred metres south west of Portela completed in 2013 provided water for the community.

Residents were reliant upon income generated from tourism, remittances from relatives who had joined the Cape Verdean diaspora, and the local to national level export of vegetables and fruit as well as produce made at the agricultural co-operative within Chã, such as crab apple and quince jams as well as wine (the most important by value). Fruits and vegetables were enclosed within tephra 'wells' that protected seedlings from the winds and provided them with access to better soils and moisture. Grapes are grown on the ground and harvested for wine, an increasingly successful export activity prior to the 2014-2015 eruption.

\section{4-2015 eruption}

Increased unrest at Fogo in late 2014 lead to progressive raising of the alert level within the established scheme (Faria 2010; Faria and Fonseca 2014) (Table 2). Following the initial unrest and alert level raise, the official meteorological and volcanological hazard monitoring agency for Cape Verde (National Institute of Meteorology and Geophysics: INMG) issued a formal alert of impending eruption to the Civil Protection on 17 October. On 22 November, the permanent monitoring network recorded numerous shallow volcano-tectonic earthquakes (Fernandes and Faria 2015). That evening, residents of Chã das Caldeiras felt earthquakes, and at approximately 10 am ( 11:00 UTC) the next day, 23 November 2014, a new eruption began. It was fed by a fissure array orientated northeast-southwest at the western base of Pico, sub-parallel to and approximately $100 \mathrm{~m}$ to the southeast of the 1995 vents. The following day, the Copernicus Emergency Management Service satellite image acquisition was activated (http://emergency.copernicus.eu; Activation ID: EMSR-111), which mapped lava flow outlines throughout the eruption (Fig. 2) to facilitate crisis management. A number of social and professional images of the eruption and its impact were also available online throughout. The flows initially advanced at approximately $35-40 \mathrm{~m} / \mathrm{h}$ (Worsley 2015) and had travelled $\sim 1.3 \mathrm{~km}$ to the southwest by the second day of the eruption (24 November: Fig. 2), where they reached the eastern edge of the 1995 lava flow and split into two flows. The flow to the southsoutheast travelled a further $1.6 \mathrm{~km}$ at a much-reduced rate. The flow to the north-northwest reduced to $\sim 20 \mathrm{~m} / \mathrm{h}$ and then $2-3 \mathrm{~m} / \mathrm{h}$ (Worsley 2015) as it advanced along the eastern edge of the 1995 ' $a$ ' $a \bar{a}$ flow and the route of the only road towards the main settlements of Portela and Bangaeira (Fig. 2). These lava flows appear to have been fed from separate vents, with flows to the south sourced from a breach on the southernmost rim of the upper vent and flows to the north-northwest sourced from the lower vents, with the flows and flow sources clearly visible in Google Earth Digital Globe images acquired on 25 and 26 November.

A number of buildings along the road to the northwest of the vent were destroyed in the first 2 days, including the newly completed (April 2014) Fogo National Park Headquarters. All of the Chã residents were evacuated during this time by the National Civil Protection Service (SNPC) and Cape Verdean Military using a track along the foot of the Bordeira cliff (Fig. 1). The Red Cross of Cape Verde and the United Nations Office Cabo Verde reported that in total 1076 people were evacuated, with 838 relocated to temporary accommodation centres and houses built in the aftermath of the 1995 eruption (IFRC 2015; UN 2014).

Table 2 The timing of alert level activations during the 2014-2015 eruption, and the alert level scheme (Faria 2010; Faria and Fonseca 2014) used by the National Institute of Meteorology and Geophysics (INMG), the official meteorological and volcanological hazard monitoring agency for Cape Verde. Times are local (UTC - 1 h)

\begin{tabular}{|c|c|c|c|c|c|c|}
\hline \multirow[t]{2}{*}{ Level } & \multirow[t]{2}{*}{ Criteria } & \multirow[t]{2}{*}{ Interpretation } & \multirow[t]{2}{*}{ Depth } & \multirow{2}{*}{$\begin{array}{l}\text { Time window for } \\
\text { possible eruption }\end{array}$} & \multicolumn{2}{|c|}{ Activation during 2014-2015 eruption } \\
\hline & & & & & Escalation & Decline \\
\hline 1 & - Usual records & Normal state & - & - & Background & 25 February \\
\hline 2 & $\begin{array}{l}\text { - Long term ground deformation } \\
\text { (GPS, InSAR) } \\
\text { - Seismic noise modification }\end{array}$ & An eruption is possible soon & 5 to $13 \mathrm{~km}$ & 10 days to 5 months & Early October & - \\
\hline 3 & $\begin{array}{l}\text { - Peak of seismic activity } \\
\text { - Variation of the tilt }\end{array}$ & Probable eruption & 4 to $5 \mathrm{~km}$ & 4 to 40 days & 21 November & 20 February \\
\hline 4 & $\begin{array}{l}\text { - Peak of the tilt } \\
\text { - Long-period events with greater } \\
\text { magnitude and number }\end{array}$ & Very probable eruption & 2 to $4 \mathrm{~km}$ & $\begin{array}{l}\text { To be determined as } \\
\text { the dike progresses }\end{array}$ & 20:00, 22 November & AM, 8 February \\
\hline 5 & $\begin{array}{l}\text { - Seismic activity is maintained } \\
\text { - Continuous tremor }\end{array}$ & Imminent eruption & 0 to $2 \mathrm{~km}$ & & 08:30, 23 November & \\
\hline
\end{tabular}


Lava entered the southwest portion of Portela on 2 December 2014. Over the following few days, the lava flow fronts slowed down to less than $1 \mathrm{~m} / \mathrm{h}$ (Worsley 2015), raising hopes that further destruction of the villages could be avoided; however, between 6 and 8 December 2014 the flows advanced and destroyed most $(>90 \%)$ of the remainder of Portela. A sheet flow and pāhoehoe lava breakout in the east of Portela, which evolved into a thin rubbly ' $a$ 'a flow on the slope between Portela and Bangaeira, led to most of Bangaeira also being destroyed (Fig. 2) (Global Volcanism Program 2015) by fast-moving flows with flow front velocities of up to $180 \mathrm{~m} / \mathrm{h}$ (Worsley, 2015). At this time there was a concern that the lava flows would continue towards the northeast, exiting the collapse scar and threatening villages, and the circum-island road, along the steep eastern flanks of the island. Rapid calculations of flow length (following Kilburn 1996) using effusion rates estimated from satellite infrared images (Ferrucci et al. 2015) suggested that this would not be the case, and in line with these estimates, the flow stalled a few hundred metres beyond the northernmost house in Bangaeira and was inactive after 18 December (Ferrucci et al. 2015; Pers. Comm. to Simon Day from Sr. Jose Antonio of Portela Village). Slow growth of a lava flow front to the west of Portela along the south side of Monte Amarelo, also in the form of a pāhoehoe breakout, continued through to mid-December but had ended by 14 December (Fig. 2). This flow covered the very last area of flat ground in Chã das Caldeiras that had fertile soil derived from the $1680 \mathrm{AD}$ phreatomagmatic ash, although similar soil is still present on the slopes of Monte Amarelo (that derives its name from the characteristic yellowishbrown colour of the phreatomagmatic ash).

In mid-December, new lava flow breakouts occurred to the west of Pico, from breaches on the west side of the main flow channel about $2 \mathrm{~km}$ from the vent, with small initial breakouts from 9 to 12 December and a large breakout by 14 December (Copernicus 2014; Ferrucci et al. 2015). These breakouts produced a westdirected flow that destroyed many agricultural fields. On 21 December, buildings within the small settlement of Ilhéu de Losna in the west of Chã were destroyed as the flow reached the talus cones at the foot of the Bordeira cliff and turned north (Fig. 2). The eruption continued at a reduced pace through late December, January and early February 2015 with periodic explosions and tephra plumes, and pulses of increased effusion rate that caused slow, intermittent lava encroachment, including a discrete flow that was emplaced near the vent in midJanuary (Ferrucci et al. 2015) and mainly covered lavas from earlier in the eruption. The formation of this last flow implies that the earlier lava flows, including any internal lava tubes, were inactive by that time and no longer capable of transporting lava to the main flow fronts. The eruption ended on the 7 February at about 20:00 (local time) with the cessation of volcanic tremor and explosions. The alert level was gradually reduced from level 4 on the 8 February to level 3 on the 20 February, and to level 1 (normal state) on the 25 February (Table 2).

The lava flows were, in broad terms, alkaline basaltic in composition (basanites), as in most previous eruptions, and were mostly characterised by ' $a$ ' $\bar{a}$ or $p \bar{a}-$ hoehoe surfaces. 'A' $\bar{a}$ flows were $0.5-2.5 \mathrm{~m}$ thick as they exited the vents and flowed down a relatively steep slope $\left(\sim 30^{\circ}\right)$, thickening to between 3 to more than $8 \mathrm{~m}$ thick as they flowed across the flatter topography between Pico and the collapse scar cliffs. Pāhoehoe flows were typically $2 \mathrm{~m}$ thick or less. Lava channels and tubes were formed throughout the flow. A lava flow volume of approximately $45 \times 10^{6} \mathrm{~m}^{3}$ was derived from comparison of pre- and post- eruption DEMs (Bagnardi et al. 2016; Richter et al. 2016). This value includes the volume of cones formed during the eruption (>55 m and $33 \mathrm{~m}$ height) and the comparison found that lavas ponded in low-lying areas $\sim 1 \mathrm{~km}$ west of Portela, producing thicknesses of up to $26 \mathrm{~m}$. This thickening is likely to have occurred by internal inflation of the flows with lava that travelled through lava tubes. The flow area south and west of Portela was still cooling and feeding local fumaroles at the time of our field visit in early 2015; limited fumarolic activity continued as late as early 2016 .

\section{Methods}

The areas in Chã assessed during our 2010 vulnerability survey have since been inundated by lava during the 2014-2015 eruption. The eruption was declared over on 7 February 2015 and, with the approval and collaboration of INMG, we carried out our field impact assessment from 24 February to 4 March 2015. The main aims of the mission were to assess the extent and nature of the damage (from both lava and ash) for buildings, infrastructure and agriculture and to sample and characterise the properties of the 2014-2015 lava flows. The damage assessment included georeferencing and cataloguing the nature of the damage and making measurements where appropriate, e.g. length and width of wall cracks, distance from flow to heat-affected item. Building or infrastructure characteristics such as construction material, wall span and size and number of openings were always recorded, and, if appropriate, tied back to the preeruption building survey that had recorded similar information in 2014 for a subset of buildings in Chã. The properties of the lava flow and the setting of the building in the area were also recorded to give some context, for example the thickness and type of lava flow, and if the building walls were oblique or perpendicular to the flow direction and in-between or within the main flow 
channels. Importantly, a large number of georeferenced photos from multiple angles were taken so that postmission analysis could easily refer back to the field observations and compare our records with media images. In addition to damage descriptions and insights, which are described over the following sections, field observations were used to ground-truth our remotely derived assessments of damage, particularly for those buildings or objects near the peripheries of the flow outline for which projection or resolution issues with the satellite images may have led to some mismatch. Below we describe our use of satellite imagery, GIS, media reports and the field data in interpreting damage observations.

Pre-eruption building locations were plotted from a Google Earth Digital Globe satellite image acquired 9 November 2014. Lava flow outlines obtained by the Copernicus Emergency Management Service (based on satellite imagery of resolution $0.5 \mathrm{~m}, 1 \mathrm{~m}$ or $3 \mathrm{~m}$ ) were then overlain on the building locations in GIS to establish the numbers of buildings affected. Plotted buildings included traditional circular scoria buildings often used as shelter by livestock or workers when tending crops. In the more densely populated villages of Portela and Bangaeira, one building footprint may have included more than one family home, where buildings are joined. Following the remote and field assessment, we classified buildings into three impact categories:

1. Destroyed buildings were completely buried, destroyed or transported from their original location by the lava flows;

2. Damaged buildings were impacted by the lava flows but still visible in situ in post-eruption satellite images (acquired 3 February 2016) and during the field mission;

3. Unaffected buildings were not in areas impacted by the lava flows and were therefore not damaged.

Syn- and post-eruption satellite images acquired 23, 25, 29 November 2014, 4 December 2014 and 3 February 2016 were used to verify the estimates of number of buildings in each category by independently mapping the condition of the building in post-eruption images. Professional media reports and photographs from professional and social media were used along with the syn-eruption satellite images to correlate reports of lava flow advancement and the reported destruction of certain buildings and/or infrastructure during the eruption. Post-eruption satellite images could also be combined with media reports to identify further resettlement and rebuilding that occurred after our field mission.

\section{Lava flow damage}

No deaths or injuries associated with the eruption were reported but most of the buildings and important areas of agricultural land, communication poles and lines and much of the only surfaced road into Chã were covered by lava. Intermittent explosions dispersed and deposited ash in the main city of São Filipe and across agricultural crops on the island, as well as affecting the airport and tourism industry. During the more intense periods of the eruption, tourism viewing of the lava flows continued to provide income for some residents of Chã; however, the time and use of vehicles involved in this prevented some residents from removing all contents and fixtures from their homes before the lava flows reached them. Other residents, however, stripped everything of value from their homes that could be moved, including plumbing fixtures, doors and windows. Equipment and stored produce from the co-operative buildings concerned with wine-making and fruitprocessing were salvaged by residents and the military, and stored along with the contents and fixtures of residential homes on the hillside of Monte Amarelo adjacent to Portela and Bangaeira villages. Some equipment and energy systems were also removed from the Park headquarters before it was destroyed. Despite these valuable actions, the loss of buildings, livelihoods and (above all) important areas of agricultural land in Chã has resulted in significant economic losses and an uncertain future for the local population. The total economic impact has been estimated as 2832 million CVE ( US\$28 million), with the contribution by sector as follows: Agriculture and livestock (42\%); Housing (27\%); Tourism (7\%); the remaining is attributed to social and cross-cutting sectors such as governance, environment and health (PDNA, 2016). In an effort to better understand the impacts of the lava flows on buildings and infrastructure, and the future hazards for displaced populations, we carried out a field impact assessment less than 3 weeks after the end of the eruption and approximately 2.5 months after the main villages were destroyed by lava. Our remote and field observations are described below and discussed in Discussion section.

\section{Buildings}

Of the approximately 350 buildings in Chã das Caldeiras, around 260 were in areas covered by lava flows during the 2014-2015 eruption (Fig. 3). Approximately 85\% $(n=210)$ of the affected buildings were concentrated within the main villages of Portela and Bangaeira to the northwest of the vents, with a further $5 \%$ (10-15 buildings) in the small village of Ilhéu de Losna, due west of the vents. Fig. 3 shows the distribution of destroyed, damaged and unaffected buildings in Chã. The majority $(n=170)$ of the 260 affected buildings were completely destroyed and/or 

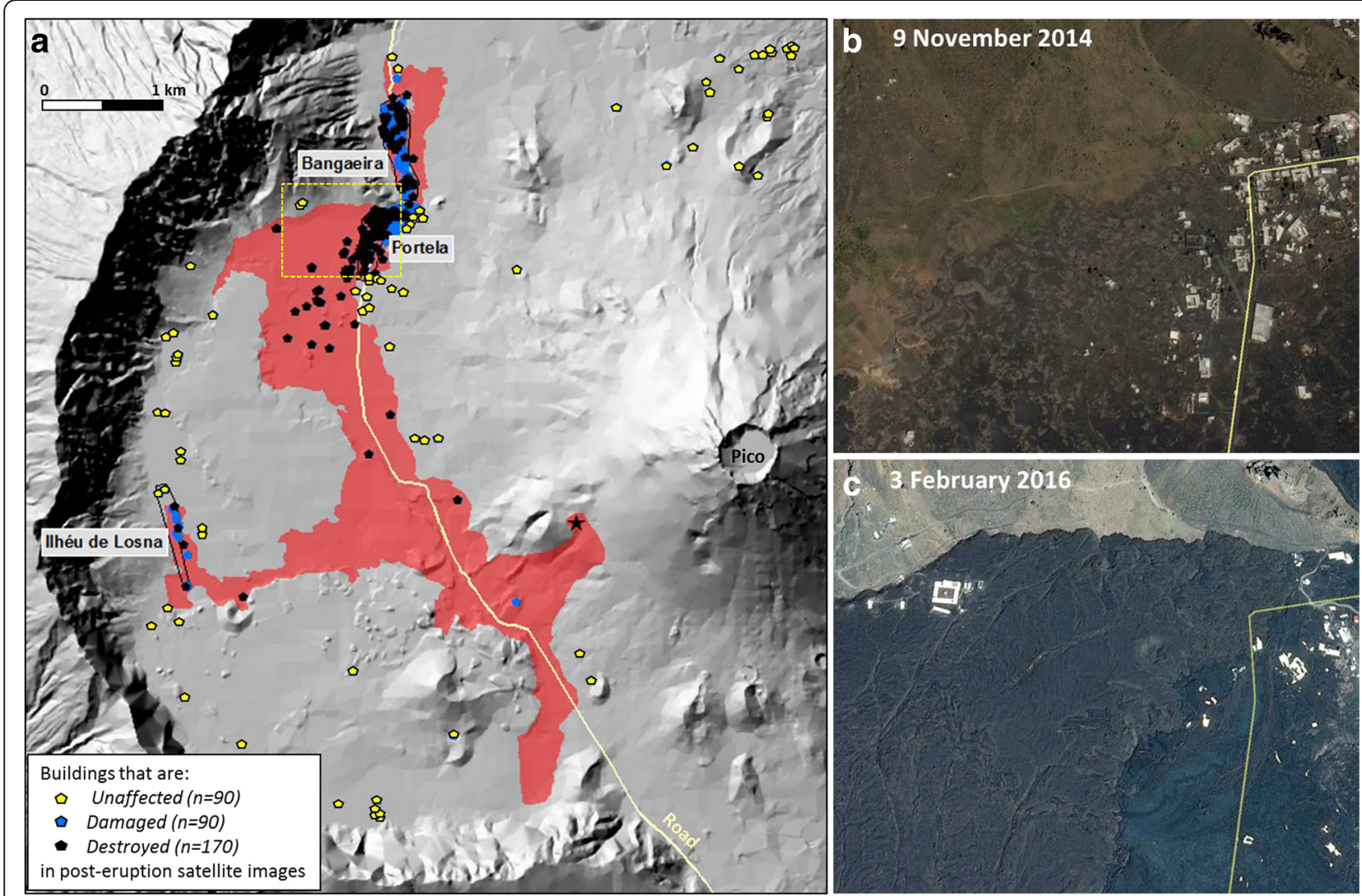

Fig. 3 a Buildings in Chã that were unaffected (yellow symbols: $n=90$ ), damaged (blue symbols: $n=90$ ) and destroyed (black symbols: $n=170)$ by the 2014-2015 lava flows; Yellow dashed box shows inset area of b Pre-eruption Google Earth Digital Globe satellite image (9 November 2014) showing the western portion of Portela village and c Post-eruption Google Earth Digital Globe satellite image (3 February 2016) showing the destruction of Portela and subsequent reconstruction of a small number of buildings on the 2014-2015 lava flows to the west of Portela

buried by the advancing flow. Destroyed buildings were particularly concentrated in the southwestern parts of Portela (Fig. 3), which was covered by the main 'a'ā flow that had a flow front up to several metres high.

Of the destroyed buildings, a small number also had parts of the building transported within the flows. Such components were typically slab reinforced concrete. For example, a number of reinforced concrete roofs were sheared from building walls by the flow and transported within the flow, some for many tens of metres (Fig. 4a). In at least fifteen cases, the roof sheared cleanly from the walls along the connection between the two, and in a further seven observed instances the wall was broken along the mortar-block interface. Household concrete water tanks in particular were observed to remain relatively intact when transported within the flow. The most

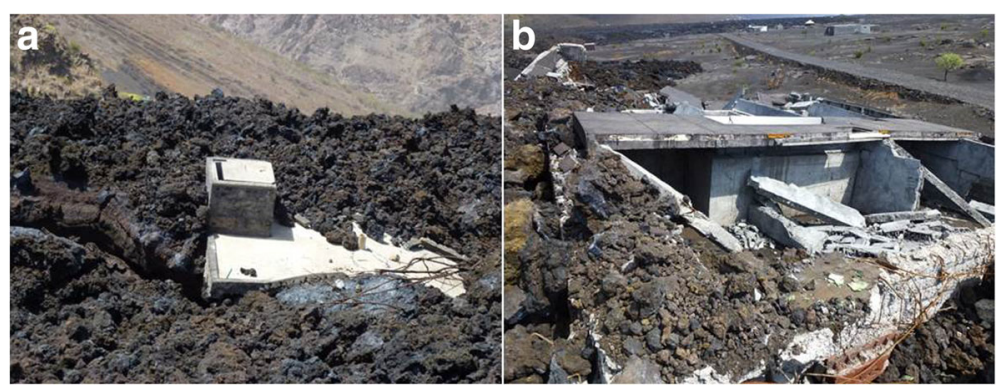

Fig. 4 a A building roof completely sheared from the walls and transported $\sim 100 \mathrm{~m}$, which showed surprisingly little damage to the concrete slab roof or the concrete water tank; $\mathbf{b}$ The water storage tank from within the newly constructed Fogo National Park Headquarters and cultural venue. The tank was transported more than $100 \mathrm{~m}$ northeast from its original location. Photographs: S.F. Jenkins, February 2015 
impressive example was that of a water storage tank from within the Park Headquarters, which was transported more than $100 \mathrm{~m}$ from its original location by the lava flows (Fig. 4b). While the building suffered damage to the roofing, walls and support beams, the overall structural envelope remained relatively intact. The remainder of the Park Headquarters was destroyed and the debris buried, although media images and reports and satellite images from the 25 November show that the flow was at first redirected around the oblique walls, before the south wall failed and flows inundated the building, entering and exiting through large existing openings.

Damaged buildings ( $n=90$ : Fig. 3 ) were not limited to the periphery of flows and showed varying degrees of damage when visited on the ground. We observed four main modes of damage that were difficult to distinguish from each other in the remote assessment of satellite images, but that could be seen in the field, as described below.

\section{Partial burial and/or inundation}

In the more eastern portions of Portela and in Bangaeira, where the pāhoehoe and rubbly ' $a$ 'a had fronts of only 2 to $3 \mathrm{~m}$ high, many buildings were simply inundated by lava with the structure remaining relatively intact and in situ (Fig. 3). For buildings with strong, or very few openings, such as the traditional, cylindrical scoria buildings characteristic of Fogo, partial burial was common (Fig. 5a) and, where visible, the structure did not seem to be obviously damaged. 'A'ā flows entering through smaller openings and into buildings was limited and consisted of scoria fall from a flow outside the entrance, rather than flow ingress; pāhoehoe flows by contrast were able to flow through relatively thin openings like doors and windows. Multiple and weaker openings often permitted ingress of both types of lava flow into, or through, a building. Despite the lack of structural damage in some cases, these buildings were left uninhabitable and of limited value to the owners. Where lava flows had entered a building through an opening, diagonal fractures from each opening corner radiated outwards along the mortar-block interface. In some instances, where lava flows reached a great enough thickness, ingress caused doming of reinforced concrete slab roofs (Fig. 5b).

\section{Minor structural damage}

Where lava flows reached a building but did not destroy, bury or enter it, there was evidence of structural damage in the form of wall cracks. This was only observed at the peripheries of the flow in Bangaeira and Ilhéu de Losna, and is likely a result of the flow slowing down and 'resting' upon the structure as it reached the end of its path. Wall cracks appeared to form most prominently at the junction between the top of the wall and the reinforced concrete roof slab. Cracks within reinforced concrete slab roofs were diagonally orientated, likely related to the direction of pressure of the lava flow.

\section{Fire and explosions}

Lava flows from the 2014-15 eruption did not cause many fires, reflecting the minimal use of flammable materials in building construction, a general lack of vegetation, and the efficient removal of flammable building contents and fittings by the residents of most buildings before the lava flows arrived. An exception was the co-operative facility, where lava had surrounded and partially entered the building, and which suffered a small fire in one part of the building. At the time of our visit, there was no evidence of what flammable material had been ignited by the lava flow.

The 2014-2015 eruption occurred near the start of the dry season (November-July) and water storage tanks in Chã are normally near full at this time of year; however, Cape Verde was experiencing severe drought in 2014 and many storage tanks were low or empty. Had they been full, then contact with lava flows could have feasibly initiated steam explosions, but we saw no evidence for that. Some concrete storage tanks showed evidence of cracks from the pressure of the lava flows, and these

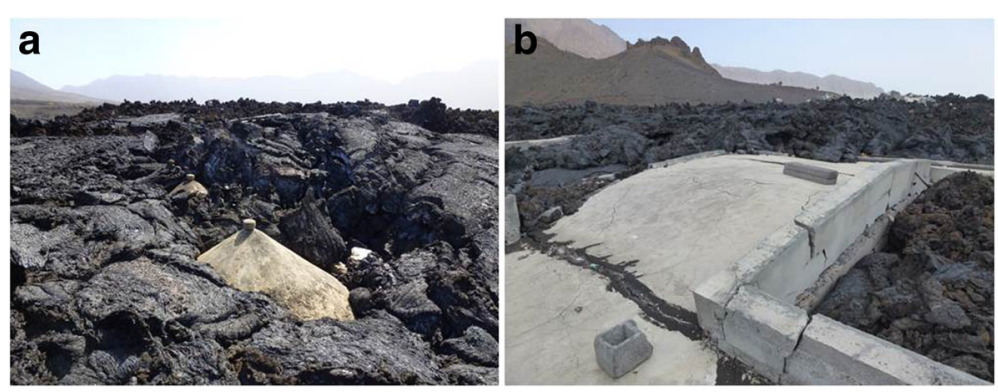

Fig. 5 a Burial of a traditionally-constructed community centre in Portela, which comprised semi-circular scoria walls up to $40 \mathrm{~cm}$ thick, with few openings; b Doming of a reinforced concrete slab roof within Portela: the building envelope remained relatively intact but lava flows inundated all of the building footprint to approximately roof height. Photographs: S.F. Jenkins, February 2015 
may have allowed the water to seep out gradually. Only one example of the explosion of a gas canister was observed (Fig. 6a and b). The explosion punctured a large hole in the wall of an otherwise intact building isolated within the lava flow.

\section{Isolation}

In Bangaeira, two parallel rubbly ' $a$ ' $\bar{a}$ flows, only about 2-3 m thick and fed by breakouts from the thicker ' $a$ ' $\bar{a}$ flow that had covered most of Portela, swept through the village. Some buildings that were on slightly raised ground resisted destruction, burial or inundation by the flows but were left isolated within the flow. In one example in Bangaeira (Fig. 6c), the surrounding agricultural land, livestock pens and water storage tanks had been destroyed leaving the residents without their livelihoods. In spite of this, the residents moved back into the building within weeks of the lava flow passing because it provided more comfortable housing than the temporary shelters. By the time of our visit ( $\sim 11$ weeks after impact), a new access route across the lava had been built by crushing the scoria surface, and people and donkeys were able to reach the property with ease (Fig. 6c). A small hotel in Bangaeira was also preparing to open at the time of our visit; lava had surrounded and isolated the building, but not entered into the courtyard or adjoining rooms.

Some buildings experienced more than one mode of damage, e.g. isolation with minor structural damage to one wall, or partial burial with an explosion caused by inundation of the lava. From our field visit, we deduced that the vast majority of buildings ( $~ 80$ to $90 \%)$ are best described by the most severe damage class: partial burial and/or inundation.

\section{Infrastructure and agriculture}

Chã had relatively little community infrastructure, with power and water generally sourced on a building-bybuilding basis prior to the 2014-2015 eruption. Our field observations of the impacts upon infrastructure and agriculture have been synthesised and are described over the following subsections.

\section{Road access}

The 2014-2015 lava flows crossed the road within the first day of eruption onset, with flows then travelling south-southeast and north-northwest. The latter, and largest flow lobe extended initially along the face of the obstruction provided by the eastern edge of the 1995 lava flow but later expanded to bury the road as well as parts of the 1995 flow. Approximately $5.7 \mathrm{~km}$ (PDNA, 2016) of the road is now covered by lava flows up to $6 \mathrm{~m}$ thick. Once the road had been cut by the lava, access to Portela and Bangaeira was gained by a dirt road between older lava flows and the Bordeira cliffs.

\section{Telecommunications}

Prior to the 2014-2015 eruption, telecommunication lines were carried into buildings in Chã from timber utility poles that ran alongside the road. These were destroyed within the first few days of the eruption as

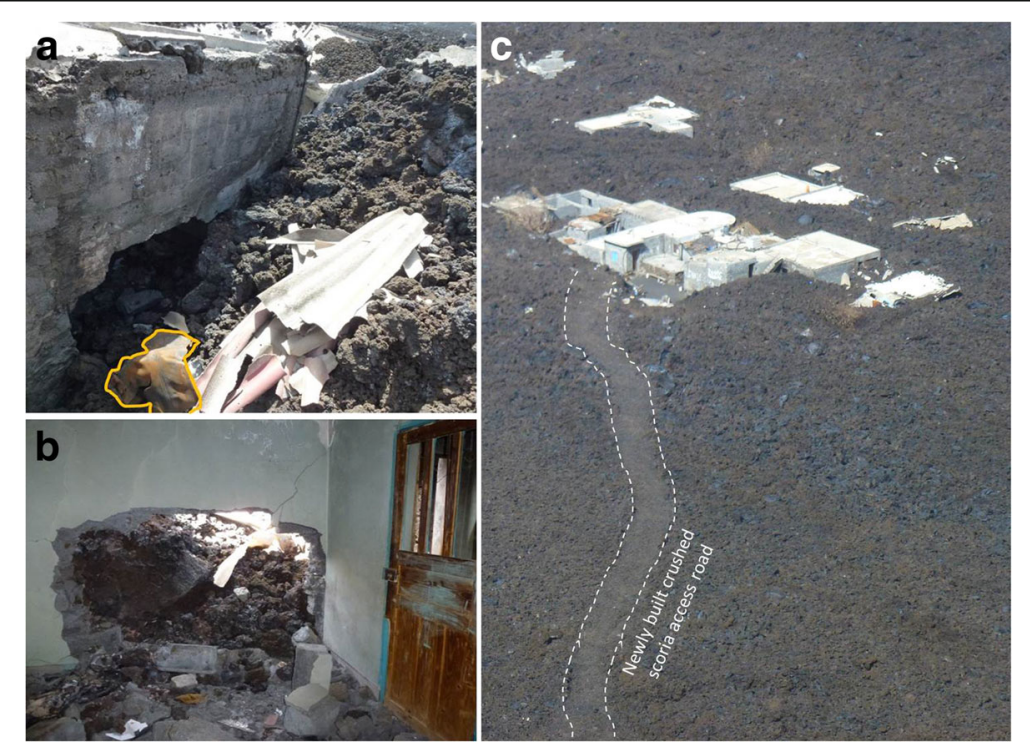

Fig. 6 a The explosion of a gas canister used for cooking (oxidised remains highlighted in orange in lower middle of photo), presumably as a result of proximity with the lava flow, $\mathbf{b}$ punctured a large hole in the side of this squared masonry building (photo taken inside building); The building remained otherwise intact; $\mathbf{c}$ A building in Bangaeira that was not inundated or destroyed by the surrounding lava flow but was left isolated within the flow. By the time of our visit, approximately 11 weeks after impact, a road had been prepared to allow the family to return and people and donkeys to transport provisions to the building. Photographs: S.F. Jenkins, February 2015 
lava flows ignited, felled and buried the poles and lines west and northwest of the vents. Replacement mobile communications were in place by the time of our visit to provide temporary mobile phone coverage. No issues with breakdown of telecommunications outside of Chã as a result of ash clouds were recorded.

\section{Water storage and sources}

Prior to the eruption, the majority of water in Chã was sourced through harvesting of rain water on concrete slab roofs. A borehole to the southwest of Portela supplemented this source, but was covered by the 20142015 lava flows. An open concrete rainfall trap reservoir between Bangaeira and Portela was also completely buried underneath the flows. At least three examples of melted or partially melted plastic water storage containers, and the pipes connecting the tanks to the building interior, were observed even though the containers did not come into direct contact with the flow. Thermal damage of plastic tanks typically had a rapid attenuation, with only the portion nearest the flow melted. In the case of a plastic water tank on top of the co-operative facility, the melted tank edge was more than $5 \mathrm{~m}$ above the flow that surrounded the building below. Concrete water storage tanks remained relatively intact upon inundation by a flow, with many transported whole on top of the flow. The large reinforced concrete rainwater storage tank in the Fogo Park Headquarters was the only structure from the building that could still be seen following the eruption: it was transported within the flow more than $150 \mathrm{~m}$ away from the headquarters. Metal structures showed strong corrosion from contact or proximity with lava flows, which would render the tanks unusable.

\section{Other infrastructure}

As discussed in Fire and explosions section, power was supplied through diesel generators and gas canisters; however, residents were able to recover most of these prior to the lava flows reaching them, so explosion of a gas canister was only observed in one building.

\section{Agriculture}

Fortunately, the eruption did not happen while grapes were due for harvest and there seemed to be no adverse impacts on observed crops from the basaltic tephra falls. The slow advance of the lava flows offered some residents the opportunity to dig up plants ahead of the flow, but $2.08 \mathrm{~km}^{2}(\sim 25 \%$ of the total: PDNA, 2016) of important agricultural land was buried underneath the 2014-2015 lava flows. In particular, the flat area of fertile soil derived from $1680 \mathrm{AD}$ phreatomagmatic ash, west of Portela, where the inhabitants used to grow vegetables has now been completely covered by lavas. In contrast, areas to the east where fruit trees and vines grown on more recent lapilli deposits were not affected by the lavas although smaller areas of vine growing south west of Portela were covered. A United Nations Post-Disaster Needs Assessment (PDNA, 2016) found that no agricultural equipment was damage or destroyed as they were salvaged before the lava flows reached them. The agricultural sector suffered the greatest economic impact from the 2014-2015 eruption as a result of damage to land and facilities and the disruption to future production. The vast majority of the losses $(98 \% ; 1171$ million CVE; US $\$ 11.6$ million) were sustained by private individuals and businesses rather than the public sector (PDNA, 2016).

\section{Discussion}

This discussion qualitatively interprets our field and remotely derived observations (Qualitative trends in observed damage section). We then examine the implications for developing non-binary fragility functions (Some pointers towards quantitative fragility functions for lava flow hazards section) before putting forward potential strategies for reducing physical vulnerability to lava flow impact, with a focus on buildings typical of Chã and those housing critical infrastructure (Building design concepts for resistance to destruction by lava flows section).

\section{Qualitative trends in observed damage}

As suggested in the pre-eruption vulnerability assessment (Jenkins et al. 2014), the physical vulnerability of a structure - as in its construction age, quality and type, the material and its orientation relative to flow - did affect the level, and perhaps method, of damage or destruction. For example, the shearing of roof slabs from a building and the development of cracks at the roof slab/ wall interface, as noted in Building section, suggests weak horizontal connections between the wall and roof. Observed failure along the mortar-block interface is suggestive of poor cohesion between mortar and block, as has been suggested for wall failure in pyroclastic density currents (Jenkins et al. 2013). A building wall perpendicular to flow and facing up-flow will experience the largest lateral pressures (either static or dynamic) and is most likely to collapse through wall failure (Blong 1984). In contrast, buildings where the flow can be diverted either side of the corner of a building were more likely to remain standing but be buried, especially for less viscous flows with low yield strength, i.e. the pāhoehoe flows. This was especially true for the traditional cylindrical buildings, potentially because the weight of a lava flow against a convex wall will place it in compression, making the same materials as used for a planar or concave wall (that would be placed into tension by the 
weight of a flow) significantly stronger. For example, the two-storey squared block masonry school in Portela was completely destroyed while a single-storey community centre, $\sim 180 \mathrm{~m}$ to the northeast, and of traditional construction with $\sim 40 \mathrm{~cm}$ thick cylindrical scoria walls, was partially buried to roof level but not transported or destroyed. Water storage tanks also exhibited low vulnerability to lateral pressures because they had been designed to withstand large lateral loads from water storage, with metal reinforcement bars and relatively small span (1-3 m) walls. We observed many water storage tanks and reinforced concrete roof slabs, because of their high structural integrity relative to masonry walls and because of their position at the top of buildings, intact but transported tens of metres at the top of the flow. We suggest that higher flow density, either in the case of pāhoehoe flows as compared to ' $a$ ' $\bar{a}$, or in the case of inflating flows, is likely to increase the vulnerability of structures to failure as a result of their buoyancy, causing them to shear off their foundations or even to float, as in the cases of the transported concrete water tanks.

Buildings in Chã are quite widely spaced and in the most densely populated areas of Portela and Bangaeira there was no evidence for buildings channelling the flows before being destroyed or partially buried. For the traditional cylindrical buildings to remain standing once inundated with lava, flows must have been diverted around the walls, although we could not find any syneruption images of this happening. Google Earth Digital Globe satellite images dated 25 November 2014 show that the oblique angled strong squared scoria western walls of the National Park Headquarters initially resisted the flow, redirecting flows around the building before it was destroyed and buried. From the satellite and media images available it is not possible to see if the flow inflated as it redirected around the walls. In the eastern portions of Portela and in Bangaeira, where flows were two to three metres thick, some slightly elevated buildings that avoided lava flow impact became isolated within the flows.

Evidence of thermal damage was limited because of the dominance of stone and concrete structures, the very arid climate and lack of vegetation, and the general removal of flammable liquids and contents from buildings before lava flow impact. Buildings in Chã relied upon diesel generators for electricity and gas canisters for cooking. As a result, the potential for explosions from the storage of fuel coming into contact with lava flows was expected to be relatively high. However, the distance of the villages from the vent $(\sim 3 \mathrm{~km}$ straight line; nearly $5 \mathrm{~km}$ flow path) and the rate of lava flow advancement gave enough warning time for most residents to remove all of the flammable building contents and fittings, including expensive commodities such as gas canisters and diesel generators. The few instances in which fires were ignited and the single instance of a gas explosion emphasise the significance of this hazard in areas with more vegetation or flammable construction types, or in cases where fuels are not removed. Where metal structures were exposed to the lava, including reinforcing bars exposed in collapsed structures as well as abandoned metal objects, corrosion damage as well as direct thermal damage was evident. Thermal and corrosion damage to metal reinforcement of concrete structures may therefore be significant in weakening of these if they are exposed to hot lava and fumarolic gases for long periods, as may decarbonation and dehydration of cement in extreme heat.

The number of buildings impacted during the Fogo eruption $(n=260)$ is comparable to most recent impacts (in the hundreds), however, there are relatively few recent examples of lava flows that have destroyed such a large proportion of a community's buildings and infrastructure (Table 1). By the time of our visit to Fogo, approximately 2 months after the villages had been impacted by lava, a number of shelters had been constructed on the slopes of Monte Amarelo and residents were returning daily to tend to the remaining crops. By February 2016, just over 1 year after the eruption of Fogo, Google Earth Digital Globe images showed that more substantial routes had been built across the lava flows to access isolated buildings and agricultural land, as well as new buildings constructed on top of the 2014-2015 lava flows (Fig. 3c). Thus, at least some residents are already rebuilding in Chã das Caldeiras, demonstrating the importance of attachment to their community and land for many residents of Chã das Caldeiras. The return of residents to areas destroyed by lava flows is not novel: residents have returned repeatedly to the Italian village of San Sebastiano, which was destroyed in $1855 \mathrm{AD}, 1872 \mathrm{AD}$ and most recently in 1944 by lava flows from Vesuvius (Kilburn 2015).

In Chã, the loss of land and the co-operative buildings will severely affect future community and commercial activities, such as tourism and the export of wine and produce. The balance of possible future agricultural production has been permanently changed by the combined effects of the 1995 and 2014-2015 lava flows, with much of the land devoted to food crops for local consumption or sale in Sao Filipe having been covered by lava flows whilst most of the land devoted to vines and fruit was unaffected. This pattern has exacerbated dependence on these cash crops and so increased the economic impact of the loss of the wine and jam production facilities in Chã during the 2014-2015 eruption. Agricultural land is assigned within Chã on a family-by-family basis so that some families have lost large swathes of agricultural land to lava flows while others have been less affected. 
However, land rights are spread through extended families in Cape Verde, and so many of those who lost their primary land will have some claim upon other plots owned by their relatives. It is not clear how or if redistribution of resources will be instigated, or to what extent complete resettlement of the villages will be possible. Richter et al. (2016) found that the former sites of Portela and Bangaeira villages are still characterised by high future lava hazard. Should relocation be appropriate, identifying the most suitable site will require consideration of the range of possible locations of future vent opening (as in Richter et al. 2016) and the likely lava flow hazard relative to other natural hazards, and in the socio-economic and cultural context of strong livelihood ties to the agricultural land. In preparing for an effusive eruption, these aspects will be more important than assessing the fragility of the building stock to lava flow impact.

Tourism was becoming an increasingly important source of income for Chã residents prior to the eruption and, with the loss of agricultural land, it is conceivable that there may be a greater focus on tourism in the future. However, significant reconstruction and rehabilitation will be required to return the villages to their pre2014-2015 eruption status/conditions. Lava covering the road during the 2014-2015 eruption meant that transport in and out of the villages and adjacent agricultural lands passed close to the Bordeira cliffs through an area prone to rockfall. Access to the villages via this track was slow, imposed additional wear on vehicles and was only easy in lightly loaded fourwheel drive vehicles leading to restrictions in the numbers of available vehicles that could use it and to additional economic costs. As in 1995, reconstructing a road into Chã will require construction over, or excavations through, the recently emplaced lava flows. In early 2016, plans were underway to develop a track and footpaths that run from Bangaeira to the northeastern corner of Chã and onto the northern flank of the island (used during the 1995 evacuations: Fig. 1) into a road. This will provide a second access (and evacuation) route from Chã and potentially support future redevelopment and rehabilitation of communities.

Given the observed damage from the Fogo eruption, we believe that a binary fragility function is still considered appropriate under most combinations of lava flow hazard and building characteristics. However, in the following subsection we consider what aspects of the flow and building characteristics are important for the development of non-binary fragility functions, i.e. for critical or costly assets. Building design concepts for resistance to destruction by lava flows section then uses these considerations to suggest how physical vulnerability may be reduced in lava flows.

\section{Some pointers towards quantitative fragility functions for} lava flow hazards

The general assumption to date of binary fragility functions for lava flow hazards means that little consideration has been given to the form of vulnerability variations and fragility functions for buildings and other exposed assets impacted by lava. These impacts may be divided into 1) Gravitational-mechanical or static load forces; 2) Dynamic-mechanical forces; 3) Permanent inundation by lava; and 4) Thermal and thermo-chemical effects. Buildings impacted by the thicker ( 4 $\mathrm{m}$ or more) but slow moving ( 1 $\mathrm{m} / \mathrm{h}$ flow front velocity) ' $\mathrm{a}$ 'ā flows were completely destroyed, while some buildings impacted by thinner $(\sim 2 \mathrm{~m})$ but faster moving (up to $\sim 180 \mathrm{~m} / \mathrm{h}$ flow front velocity) 'a'a flows remained intact. This implies that for ' $a$ ' $\bar{a}$ flows at least the gravitational forces, linked to flow thickness, dominate over dynamic forces linked to flow velocity and rheology. Therefore, fragility functions consistent with this pattern of destruction should relate to flow thickness and density more than to flow velocity and rheology. However, we recognise that the latter are controls upon flow thickness and so an indirect dependence will exist.

In contrast to the analogy of water inundation, where water drains away and buildings can be dried out, inundation with lava is likely to completely destroy the value of a building (or at least its inundated floors). This is especially true in the case of pāhoehoe lava, which requires much effort to break up and may be impossible to remove without damaging the building structure. Furthermore, our observations indicate that ingress of ' $a$ 'a into a building through small openings is much less rapid than ingress of pāhoehoe through openings of similar size. Pāhoehoe lava and inflating lava flows of all types therefore present a much greater inundation risk than do ' $a$ ' $\bar{a}$ flows of similar thickness.

The survival of some masonry and concrete buildings impacted by lavas in Chã das Caldeiras, in contrast to the complete destruction of wooden buildings by fire in communities inundated by lava in Hawai'i supports the obvious point that heat resistance in construction materials is essential for avoidance of complete vulnerability of buildings to lava flows. More subtly, our observations indicate that flammable and potentially explosive fuels and other liquids must be removed or else carefully protected from heat (for example in underground tanks) prior to lava flow impact; and that thermochemical impacts such as corrosion of metal objects by hot reactive gases may be an important hazard to otherwise protected buildings and contents.

\section{Building design concepts for resistance to destruction by lava flows}

The previous section indicates some clear trends that could form the basis for building design concepts. For 
typical structures built by Chã residents, such as domestic housing, agricultural buildings and small commercial buildings, a key consideration is capital cost of materials. The first and simplest measure, following existing local practice for levelling ground before construction of houses on gentle slopes, would be to build upon a rubble pedestal raised some 1-2 $\mathrm{m}$ above the surrounding ground. Resistance to lava flows of existing buildings could be increased by reverting to the roundhouse style of construction, or thickening rectilinear walls to the $40 \mathrm{~cm}$ typical of roundhouses. Closely spaced internal load-bearing walls would significantly buttress such thick external rectilinear walls, by analogy with buttress dam construction (Schnitter 1994). Additionally, outwardfacing openings at the ground floor level should be on the downslope side and could be strengthened or recessed and blocked with rubble stone in the event of an eruption. Roof level (or upper storey) access should be possible so that the building can be accessed posteruption, even if the entrance has been blocked by lava.

Critical structures and infrastructure built by the government or other external agencies may require high levels of protection either because of political and economic costs associated with their provision leading to a low tolerance of risk of loss, or because of the wider impacts of their loss. Greater expenditures to reduce those risks might therefore be acceptable. For those infrastructure elements that can be co-located but not easily placed on high ground, such as deep wells and heavy generators, a single large multi-use structure would be preferable. Given the advantages of outward curved walls, convex toward the pressure as in arch dams, this would likely resemble a circular tower with thick and high quality (pre-stressed reinforced concrete or masonry) external walls. The building would also benefit from outward-sloping walls as in slab buttress dams (Schnitter 1994) and strong ground anchoring to withstand buoyancy forces, and an outward-sloping pedestal to raise any openings and promote escape of hot gases in the lava. Service pipes (for example, water pipes leading from a well head) should be buried below the surface or else cut and sealed in the event of an eruption. If only limited access to the structure was required, the entrance could be at roof level and accessed by an external ladder or spiral stair, a jib crane or hose (for liquids such as generator fuel).

\section{Conclusions}

The Fogo eruption was one of the most devastating lava flow impacts in recent times. The majority $(\sim 75 \%)$ of buildings and $25 \%$ of important agricultural land $\left(\sim 2 \mathrm{~km}^{2}\right.$ out of a total of $8.5 \mathrm{~km}^{2}$ of cultivable land: PDNA, 2016) in the isolated Chã das Caldeiras community was damaged or destroyed. Post-eruption field assessments confirmed that a binary vulnerability function for lava flows is generally appropriate, especially for agricultural land, but that the mode of damage differs. Fire and explosions from interaction of lava flows with vegetation, buildings or contents such as gas canisters were limited at Fogo, because of the arid environment and the very effective removal of building contents and fittings by residents and the military prior to lava flow inundation. The principal observed impact of lava flows was the burial of physical structures and land. Depending upon the nature of the structure impacted by the lava, the object was buried, inundated or transported by the flow. However, the traditional cylindrical buildings constructed with thick scoria walls were found to be particularly resistant to lava flows because of their very strong resistance to lateral pressures, and potentially their ability to divert lava around their walls, with those that could still be seen partially buried but not destroyed by the flow. Even where buildings remained intact, lava flows still rendered them uninhabitable and unusable through burial or flow ingress through openings such as doors or windows; the loss of original function was therefore still total. A small number of buildings in Bangaeira were not damaged by the lava flows but were isolated between flow channels, making access difficult and destroying land associated with the property.

The major impact for infrastructure and agriculture was their burial by lava. Land used for agriculture or settlements has been rendered unusable for many decades and retrieval of infrastructure is mostly impossible. Fortunately, the timing of the eruption did not interfere with grape harvesting, the most valuable crop in Chã.

The greatest damage occurred in areas affected by thick (several metres) 'a'ā flows, which produced higher forces upon the structures that they encountered, than the thinner (few metres) but faster-moving pāhoehoe flows, where damage was limited to partial burial and/or inundation by lava. The pre-eruption vulnerability and posteruption damage assessments were used in combination to identify the key lava and building characteristics that influence impact. For the basaltic pāhoehoe and ' $a$ 'ā lava flows that dominate at Fogo, the curvature, thickness and short span of the walls of traditional cylindrical buildings, as well as the lack of multiple openings such as doors or windows, seemed to prevent destruction or the ingress of lava into the building interior. Our observations enabled us to propose building design strategies that could be employed in Chã and similar locations on other dominantly effusive volcanoes to increase the resistance of both typical structures and special purpose structures housing critical infrastructure. The rapid rebuilding of the villages after the 1995 eruption, largely on their old sites, shows a high level of acceptance of lava flow risk by Chã residents. In contrast, the slow restoration of services after 1995 and the initial opposition to resettlement of Chã das 
Caldeiras by the government in 2015 shows that there is, in general, a lower level of lava flow risk acceptance for public buildings and infrastructure. The proposed mitigation strategies are tentative but challenge the notion of purely binary fragility functions. We emphasise that in the absence of strong imperatives for resettlement of high lava flow hazard zones, the best method for reducing lava flow risk to buildings and infrastructure remains the re/location of structures in areas of relatively low lava flow hazard.

\section{Acknowledgements}

We thank Sr. Jose Antonio Fonseca of Portela village and Brendon Rolfe-Betts for assistance in fieldwork. We are also grateful to Chris Kilburn (UCL), Laura Connor, Jacob Richardson, Chuck Connor and Sylvain Charbonnier (USF) who supported emergency management efforts by assisting in lava flow modelling and flow path and runout estimation during the crisis. Giuseppe Cornaglia, from the Portuguese Civil Protection Agency, was instrumental in the activation of the Copernicus Emergency Management Service at the early stage of the eruption. We are grateful to Earth Observatory of Singapore for covering the open access fees. Finally, we sincerely thank Jim Kauahikaua and an anonymous reviewer, as well as the guest editor Natalia Deligne, for their insightful coments and feedback that greatly improved the manuscript.

\section{Funding}

SFJ is grateful for funding from the Earth Observatory of Singapore and NERC's Impact Accelerator Fund for hazard and risk assessment at high-risk volcanoes. JFBDF acknowledges funding from Fundação para a Ciência e Tecnologia, Portugal, as emergency support immediately after the onset of the eruption, and through project FIRE (contract PTDC/GEOGEO/1123/2014).

\section{Authors' contributions}

SFJ carried out 2010 pre-eruption vulnerability assessments, and SFJ and SD carried out post-eruption fieldwork to investigate the 2014-2015 lava flows and their impact. BF and JFBD aided both field visits, associated studies and interpretations and have supported a long-standing collaboration on Fogo. All authors have read and approved the final manuscript.

\section{Competing interests}

The authors declare that they have no competing interests.

\section{Publisher's Note}

Springer Nature remains neutral with regard to jurisdictional claims in published maps and institutional affiliations.

\section{Author details}

${ }^{1}$ School of Earth Sciences, University of Bristol, Bristol, UK. ${ }^{2}$ Earth Observatory of Singapore, Nanyang Technological University, Singapore, Singapore. ${ }^{3}$ Institute for Risk and Disaster Reduction, University College London, London, UK. ${ }^{4}$ National Institute of Meteorology and Geophysics, São Vicente, Cape Verde. ${ }^{5}$ CERENA, Instituto Superior Tecnico, University of Lisbon, Lisbon, Portugal.

\section{Received: 29 April 2016 Accepted: 9 March 2017}

Published online: 20 March 2017

\section{References}

Bagnardi M, González PJ, Hooper A. High-resolution digital elevation model from tri-stereo Pleiades-1 satellite imagery for lava flow volume estimates at Fogo Volcano. Geophys Res Lett. 2016;43(12):6267-75.

Baxter P, Allard P, Halbwachs M, Komorowski JC, Woods A, Ancia A. Human health and vulnerability in the Nyiragongo volcano eruption and humanitarian crisis at Goma, Democratic Republic of Congo. Acta Vulcanol. 2002;14-15(1-2):109-14.

Behncke B, Neri M, Nagay A. Lava flow hazard at Mount Etna (Italy): New data from a GIS-based study. In: Manga M, Ventura G, editors. Kinematics and Dynamics of Lava Flows. Colorado: Geological Society of America: Special Paper 396 Boulder; 2005.
Blong RJ. Volcanic hazards: a sourcebook on the effects of eruptions. Academic Press Australia, North Ryde, New South Wales; 1984. p. 424.

Bulletin of the Global Volcanism Network (BGVN 20:03). New eruption on 2 April generates lava flows within the caldera. Washington DC: Smithsonian Institution (editor). BGVN 20:03; 1995.

Calvari S, Pinkerton H. Formation of lava tubes and extensive flow field during the 1991-1993 eruption of Mount Etna. J Geophys Res Solid Earth. 1998;103(B11):27291-301.

Copernicus. Emergency Management Service, EMSR111: Volcanic eruption at Fogo Island (Cape Verde). 2014. http://emergency.copernicus.eu/mapping/ list-of-components/EMSR111.

Day SJ, Heleno da Silva SIN, Fonseca JFBD. A past giant lateral collapse and present-day flank instability of Fogo, Cape Verde Islands. J Volcanol Geotherm Res. 1999;94(1-4):191-218.

Day SJ, Carracedo JC, Guillou H, Pais Pais FJ, Badiola ER, Fonseca JFBD, Heleno SIN. Comparison and cross-checking of historical, archaeological and geological evidence for the location and type of historical and sub-historical eruptions of multiple-vent oceanic island volcanoes. Geol Soc Lond, Spec Publ. 2000;171(1):281-306

FAO. FAO provides urgent assistance to drought-stricken Cape Verde. In: Food and Agriculture Organization of the United Nations. 2015. http://www.fao. org/news/story/en/item/278021. Accessed 8 Mar 2016.

Faria B. Monitorização Geofísica do Vulcão do Fogo e Níveis de Alerta. Ph.D thesis. Universidade Técnica de Lisboa. In, Portuguese. 2010.

Faria B, Fonseca J. Investigating volcanic hazard in Cape Verde Islands through geophysical monitoring: network description and first results. Nat Hazards Earth Syst Sci. 2014;1:1-36.

Felpeto A, Araña V, Ortiz R, Astiz M, García A. Assessment and modelling of lava flow hazard on Lanzarote (canary islands). Nat Hazards. 2001;23(2):247-57.

Fernandes R, Faria B. FOGO-2014: monitoring the Fogo 2014 eruption, Cape Verde. In: European Geoscience Union General Assembly. Vienna: Copernicus; 2015.

Ferrucci F, Day S, Hirn B, Faria B, Zoffoli S. Multi-payload Multi-platform Tactical Monitoring and Evaluation of the 2014 Eruption of Fogo, Cabo Verde. In: European Geoscience Union General Assembly. Geophysical Research Abstracts, Vienna; 2015.

Fonseca JFBD, Faria BVE, Lima NP, Heleno SIN, Lazaro C, d'Oreye NF, Ferreira AMG, Barros IJM, Santos P, Bandomo Z, Day SF, Osorio JP, Baio M, Matos JLG. Multiparameter monitoring of Fogo Island, Cape Verde, for volcanic risk mitigation. J Volcanol Geotherm Res. 2003;2605:1-18.

Global Volcanism Program. Report on Fogo (Cape Verde). In: Sennert SK, editor. Weekly Volcanic Activity Reports, 19 November 2014-24 February 2015. Smithsonian Institution and US Geological Survey, Washington DC; 2015.

Global Volcanism Program. Weekly Reports: 3 to 9 December 2014. In, Weekly Reports of the Global Volcanism Network: Smithsonian Institution, Washington DC; 2014.

Global Volcanism Program (1976) Report on Karangetang (Indonesia). In: Squires D (ed) Natural Science Event Bulletin, 1:13. Smithsonian Institution. http://dx.doi.org/10.5479/si.GVP.NSEB197610-267020.

Global Volcanism Program (1992) Report on Kilauea (United States). In: McClelland L (ed) Bulletin of the Global Volcanism Network, 17:12. Smithsonian Institution. http://dx.doi.org/10.5479/si.GVP.BGVN199212-332010.

Global Volcanism Program (1977a) Report on Nyiragongo (DR Congo). In: Squires, D (ed.), Natural Science Event Bulletin, 2:2-3. Smithsonian Institution. http://dx.doi.org/10.5479/si.GVP.NSEB197703-223030.

Global Volcanism Program (1977b) Report on Piton de la Fournaise (France). In: Squires, D (ed.), Natural Science Event Bulletin, 2:4. Smithsonian Institution. http://dx.doi.org/10.5479/si.GVP.NSEB197704-233020.

Harris AJL. Basaltic lava flow hazard. In: Papale P, Eichelberger JC, Loughlin SC, Nakada S, Yepes H, editors. Volcanic hazards, risks and disasters. Elsevier; Amsterdam, 2015. p. 17-46.

IFRC. Emergency plan of action: Preliminary final report; Cape Verde: Volcano (Fogo). International Federation of Red Cross and Red Crescent Societies. In: DREF no. MDRCV002; 2015. http://reliefweb.int/sites/reliefweb.int/files/ resources/MDRCV002pfr.pdf. Accessed 16 Mar 2017.

Jenkins S, Komorowski JC, Baxter P, Spence R, Picquout A, Lavigne F, Surono. The Merapi 2010 eruption: An interdisciplinary impact assessment methodology for studying pyroclastic density current dynamics. J Volcanol Geotherm Res. 2013;261:316-29.

Jenkins SF, Spence RJS, Fonseca JFBD, Solidum RU, Wilson TM. Volcanic risk assessment: Quantifying physical vulnerability in the built environment. J Volcanol Geotherm Res. 2014;276:105-20. 
Kilburn CRJ. Patterns and predictability in the emplacement of subaerial lava flows and flow fields. In: Scarpa R, Tilling Rl, editors. Monitoring and mitigation of volcano hazards. Berlin: Springer; 1996. p. 491-537.

Kilburn CRJ. Lava flow hazards and modeling. In: Sigurdsson H, Houghton BF, McNutt SR, Rymer H, Stix J, editors. Encyclopedia of volcanoes. San Diego: Academic; 2015. p. 957-69.

Masson DG, Le Bas TP, Grevemeyer I, Weinrebe W. Flank collapse and large-scale landsliding in the Cape Verde Islands, off West Africa. Geochem Geophys Geosyst. 2008;9(7):n/a-n/a.

PDNA (2016) Post-Disaster Needs Accessment Report, Gabinete de Reconstrução do Fogo, Paia, Cape Verde, https://www.gfdrr.org/acp-eu/cabo-verde-postdisaster-needs-assessment-2015

Rhodes JM, Lockwood JP, Trusdell FA. Lava flow hazards and risk assessment on Mauna Loa volcano, Hawaii. In: Rhodes JM, Lockwood JP, editors. Mauna Loa revealed: structure, composition, history, and hazards. Washington, D. C: American Geophysical Union; 2013.

Ribeiro O. A ilha do Fogo e as suas erupções. Junta de Investigaçôes do Ultramar. 1960

Richter N, Favalli M, de Zeeuw-van Dalfsen E, Fornaciai A, Fernandes R, Perez Rodriguez N, Levy J, Victoria SS, Walter TR. Lava flow hazard at Fogo volcano, Cape Verde, before and after the 2014-2015 eruption. Natural hazards and earth system sciences discussions. 2016.

Schnitter N. A history of dams: the useful pyramids. Balkema, Amsterdam; 1994.

UN. Initial Assessment Report. Volcano eruption, Republic of Cabo Verde. In: Prepared by UNDAC and the United Nations Office Cabo Verde. 2014. http://reliefweb.int/report/cabo-verde/initial-assessment-report-cabo-verdevolcano-eruption. Accessed 16 Mar 2017.

Walker $\mathrm{G}$. The endogenous growth of pahoehoe lava lobes and morphology of lava-rise edges. Studies in volcanology - the legacy of George Walker (Special Publications of IAVCEI No. 2). The Geol Soc. 2009;17-32.

Williams, RS, and Moore, JG, 1983, Man Against Volcano: The Eruption on Heimaey. Vestmannaeyjar, Iceland. United States Geological Survey Open File Report. https://pubs.usgs.gov/gip/heimaey/heimaey.pdf.

WorldAtlas. In, Cape Verde History Timeline. 2011. http://www.worldatlas.com/ webimage/countrys/africa/capeverde/cvtimeln.htm. Accessed 16 Mar 2017.

Worsley (2015) Physical geology of the Fogo volcano (Cape Verde Islands) and its 2014-2015 eruption. Geology Today 31(4).

\section{Submit your manuscript to a SpringerOpen ${ }^{\circ}$ journal and benefit from:}

- Convenient online submission

- Rigorous peer review

- Immediate publication on acceptance

- Open access: articles freely available online

- High visibility within the field

- Retaining the copyright to your article 